INFORMASI - ISSN (p) 0126-0650; ISSN (e) 2502-3837

Vol. 49. No. 1 (2019).pp 11-24.doi: http://doi.org/10.21831/informasi.v49i1.23115

\title{
THE PERSUASIVE DA'WAH COMMUNICATION OF KH ASYHARI MARZUQI AND ITS IMPLICATIONS IN MODERN LIFE
}

\author{
Anton Prasetyo \\ anton21jogja@gmail.com \\ Magister Komunikasi dan Penyiaran Islam \\ Fakultas Dakwah dan Komunikasi \\ Universitas Islam Negeri Sunan Kalijaga Yogyakarta
}

\begin{abstract}
This research was aimed to find out one of the Da'wah activists, namely KH Asyhari Marzuqi in delivering Da'wah material. Was it using persuasive words or just the opposite, coercive that causes fear? By using persuasive communication theory and other related theories, researchers analyzed the data using qualitative research methods. The approach used in this study was a case study. Data analysis model was with explanation development. Qualitative research is identical to a critical and interpretative research. After conducting the research, the researcher obtained the result that KH Asyhari Marzuqi was a figure of Da'i who was able to preach persuasively. As a communicator, he meets the standards for persuasive da'i. Meanwhile, the message delivered was also a language of invitation that is soft and without coercion.
\end{abstract}

Penelitian ini bertujuan untuk mengetahui salah satu aktivis dakwah, yakni KH. Asyhari Marzuqi, dalam menyampaikan materi dakwah. Apakah menggunakan katakata persuasif atau justru sebaliknya, koersif yang menimbulkan ketakutan? Dengan menggunakan teori komunikasi persuasif dan teori terkait lainnya, peneliti menganalisis data dengan menggunakan metode penelitian kualitatif. Pendekatan yang digunakan dalam penelitian ini adalah studi kasus. Model analisa data dengan pengembangan penjelasan. Penelitian kualitatif identik dengan sebuah penelitian yang bersifat kritis dan interpretatif. Setelah melakukan penelitian, peneliti mendapatkan hasil bahwa KH Asyhari Marzuqi merupakan sosok da'i yang mampu berdakwah secara persuasif. Sebagai seorang komunikator, ia memenuhi standar untuk dikatakan da'i persuasif. Sementara, pesan yang disampaikan juga berupa bahasa ajakan yang bersifat lembut dan tanpa paksaan.

Keywords: Persuasive Communication, Da'wah, KH Asyhari Marzuqi 


\section{INTRODUCTION}

Islam is one of the preaching religions in the world. In 1873, Max Muller classified religion into two, namely religious preaching and non-missionary religion (missionaries and non-missionaries). Among the religions of Da'wah is Islam, with Christianity, and Buddhism. While non-Da'wah religions are Jewish, Hindu and Zoroastrian. While in 1896, Thimas W. Arnold said that the preaching religions are Islam, Christianity and Judaism.

In Islam, the history of Da'wah can be divided into four periods: the first period, about the preaching of the Prophets before the Prophet Muhammad. The second period was the period of the Prophet Muhammad and Khulafa 'al-Rashidin. The third period, was during the reign of the Umayyad, Abasiy and Ottoman dynasties. Fourth period is modern times. In the first period, since Noah to Prophet Isa, Islamic historians agreed that they were da'i messengers of Allah who invited to the unity (pengesaan Tuhan) and fight idolatry, told obedience, and prevent immoral acts (Faizah, 2015: 26).

Furthermore, Faizah explained that the third period was the period of the Umayyad, Abasiyya, and Ottoman dynasties. This period began with the establishment of the Umayyad Dynasty by the Mu'awiyyah ibn Abi Shafyan in the fortieth year of the Hijrah to the collapse of the Ottoman dynasty in 1343 H/ 1924 AD (Faizah, 2015: 26). During this period Islamic propaganda became more widespread, reaching Asia Minor, Rome, North Africa, Andalusia, and so on.

In this period, Islamic sciences, such as philosophy, theology, Islamic laws, and mysticism developed rapidly. In the field of philosophy known as al-Kindi, al-Farabi, Ibn Sina. In the field of theology known as Imam Hasan al-Ash'ari, al-Ghazali, and others. In the field of Islamic law, it is known as Imam Hanafi, Imam Malik, Imam Syafii, and Imam Ibn Hambal (Faizah, 2015: 26).

The fourth period is modern times. The history of modern Islamic Da'wah is a very broad discussion so it is not possible to see it in its entirety (Faizah, 2015: 27). Compared to other religions, in this modern era, Islam suffered defeat in preaching. In fact, compared to Christians and Jews, Islam is in the last place.

Taqiyuddin once said that the decline of the Islamic world was due to the weak understanding of the people of Islam that was very severe, which damaged the minds of Muslims suddenly. In addition, the method of delivering Da'wah is also often not well received by mad'u. This is inseparable from the assumption that Da'wah is identical to the sword.

In fact, Allah gave guidance to the da'i so that the preaching they did should be well organized by using effective or efficient methods or methods according to the conditions and conditions that exist in the elements of Da'wah (Yahya, 2016: 91). Da'wah activities will always be full of audiences or mustami 'who are faithfully listening to Da'wah, if the preachers or da'i master effective ways of communicating (Markarma, 2014: 128). Starting from here there is an imbalance of the theory and practice of Da'wah in the modern era. Da'wah should be carried out in a persuasive way but in fact is coercive. However, not all da'i in the modern era always use coercive methods.

K.H. Asyhari Marzuki is one of the da'i in modern times. All activities lead to Da'wah activities, thevalue of struggle for thesentence sentence (Munir, 2009: 109). Da'wah carried out by K.H. Asyhari Marzuqi in the middle of the pesantren was manifested in the form of the recitation of various books written by the salaf scholars, where the recitation was followed by the santri in and outside santri (Munir, 2009: 112). Meanwhile, there is also a study of the book or majlis taklim for the outside community, which is held every Sunday morning and Sunday afternoon (Munir, 2009: 113).

In the introduction to his work, K.H. Asyhari Marzuqi said, "The recitation on Sunday morning that we usually do is basically a means of warning and deepening religion. Then there is nothing we should do except to see ourselves, correct ourselves, 
then eliminate mistakes with kindness and mengistiqomahkan and increase religious experience (Marzuqi, 2012: viii).

Students who continue the K.H missionary struggle. Asyhari Marzuqi, among others, K.H. Muslim Nawawi (Caregiver of An-Nur Ngrukem Islamic Boarding School), Hamami Zada (Syarif Hidayatullah UIN Lecturer), Muhaimin (Religious Affairs Ministry Extension), and others. Meanwhile, the missionary institutions include Nurul Ummah Islamic Boarding School, Nurul Ummah Kindergarten, MI Nurul Ummah, MTs Nurul Ummah, and MA Nurul Ummah.

Based on the explanation on the background of the problem, two problems can be formulated (1). What is the intellectual history of K.H. Asyhari Marzuqi? (2). How is persuasive preaching carried out by K.H. Asyhari Marzuki?

\section{LITERATURE REVIEW}

There are 2 (two) studies in the form of journalsand theses that examine K.H. Asyhari Marzuqi. The first is research in the form of a journal conducted by Aina Noor Habibah with the title "The Thought of Sufism, K.H. Asyhari Marzuqi and Its Implications in Modern Life “.

In this study, Aina explained that there was a difference between Sufism and Islamic thinking which existed in the early days of Sufism's growth with thoughts carried out by K.H. Asyhari Marzuqi. The thought of Sufism in the early days of the growth of Sufism emphasized ritual aspects and had stages to reach the highest level. Meanwhile, the thoughts of Sufism, Akhlaqi K.H. Asyhari Marzuqi emphasizes the ritual aspects that are social, moral, and know science and technology for religion.

Second, the thesis written by Bambang Hadiyanto with the title "The Role of Kiai Asyhari Marzuqi in the Development of Education in the Nurul Ummah Kotagede Islamic Boarding School 1986-2004 AD". This study focuses on the role of K.H. Asyhari Marzuki in developing religious education, both through Islamic boarding schools, madrasah diniyah, or other formal and nonformal institutions.

Although the two previous studies (prior research) have similar topics, namely researching K.H. Asyhari Marzuki, but this study has a difference. In this study, researchers focused more on K.H's persuasive preaching; Asyhari Marzuki and its implications in modern life.

In order to analyze existing data, researchers will use several theories so that they can produce good research. Here are the theories that researchers will use:

\section{Da'wah}

The word "Da'wah" is etymologically derived from Arabic, derived from the word da'a, yad'u, da'watan which means to call (Alifuddin, 2015: 181). In terminology, Da'wah according to Sheikh Ali Makhfudz is a process that encourages human beings to do well, and follows instructions, calls on them to do good and forbids evil deeds, so that they can get world happiness and the hereafter (Abzar, 2015: 40).

The preacher is not a determinant, but a driver. The preacher encourages Da'wah partners through missionary message creations (al-Da'wah bi al-maqal wa alkitabah) and environmental creations (alDa'wah bi al-hal) (Faizah, 2006: 127). Da'wah carried out by the dai has the priority of virtue, namely to raise the banner of truth and bring goodness so that the people become good so that they will always carry out the good and prevent munkar (Zaini, 2013: 95).

\section{History}

History comes from the Malay language, which absorbs the syajarah word from Arabic which means tree, descent, origin, genealogy, history. Meanwhile, in English the word history refers more to the word history. History has a very important role in human life, namely as a warning if history is dark so it does not happen again. However, if history is good, its kindness can be imitated.

Historians who made reconstruction of reality also depend on the theme chosen. The history of political writing politics, the 
economic history of writing economic life. (Kuntowijoyo, 2004: 20). Here, researchers write K.H's intellectual history. Asyhari Marzuqi related to the implementation of his Da'wah.

\section{Persuasive communication}

Persuasive communication consists of two words, namely communication and persuasive. According to the large Indonesian dictionary, as quoted by Sariani (2014), the term communication is defined by the sending and receiving of messages or news between two or more people so that the message in question can be understood.

Harold Lasswell said that the best way to explain communication is to answer the question, "Who Says What In Which Channel To Whom With What Effect?"

Burgon and Huffner divide communication into three types of patterns, namely (Maulana, 2013: 7):

a. Assertive Communication, namely communication skills that are able to express opinions straightly to other people (communicants) but not hurt or offend verbally or nonverbally (there is no verbal and nonverbal aggression).

b. Passive communication, which is a communication pattern that does not have maximum feedback so that the communication process is often ineffective.

c. Communication aggression, namely the pattern of communication that expresses opinions / information or messages in a straightforward manner but there are verbal and nonverbal aggression.

The term persuasion comes from Latin words, persuasio, which means to persuade, invite or seduce. Persuasion can be done rationally and emotionally. In a rational way, the cognitive component in a person can be influenced. Aspects that are influenced in the form of ideas or concepts. Persuasion that is done emotionally, usually touches the affective aspects, namely things related to one's emotional life. Through emotional methods, aspects of sympathy and empathy one can be moved (Farnas and Gumelar,
2013: 27).

According to Bettinghaus as quoted by Putri (2015), persuasion is an effort to influence one's thoughts and actions, or the relationship of activity between the speaker and the listener where the speaker tries to influence the behavior of the listener through the intermediary of hearing and sight.

Referring to this understanding, persuasion communication is included in the assertive pattern because there is no aggression. Persuasive communication is a psychological activity, namely a communicator tries to influence opinions and even acts of the communicant with psychological manipulation, so the communicant acts according to his own will.

In addition, to be able to run the persuasion method, several components of communication are needed that must be fully involved and closely related to each other. The following will be described in each component (Maulana, 2003: 10-11):

\subsection{Communicator}

Communicators are people who convey communication messages so that they can be delivered and be understood by the recipient. To be able to use the persuasion method efficiently, a librarian who acts as a communicator must bea person who has high credibility (measured by oral and written communication skills, pleasant appearance, convincing attitude, high confidence) so as to foster trust for those who receive messages . If there are no people in the library with these criteria, you can also ask for help (hire) people who are experts as consultants or direct actors.

Besides credibility, communicators are also required to positively assess and support communication objectives. Communicators must also be open and honest. The recipient of the message must not see any impression of dishonesty in the communicator. To be able to know what is really desired and liked by the target of communication, a communicator must have empathy or sensitivity to what is felt by the target so that he feels cared for. People really like being noticed, and that is 
what a communicator should give.

\subsection{Communication Message}

After the communicator is selected, the second component that must also be treated very carefully is the communication message. Unlike the information message that is very strong in giving instructions or suggestions for action, or with a coercion message that is felt and very clear the impression of the threat delivered, the persuasion message must be very subtle and almost imperceptibly "forced". The message may not feel directed at the target, but rather impresses that the message is for someone else. There are no instructions in it but examples of the actions of others.

\section{METHODS}

In this study, researchers used qualitative research methods. The approach used in this study is a case study. Data analysis model used in this study is explanation development. Qualitative research is identical to a critical and interpretative research.

Qualitative research can be constructed as a research strategy that usually emphasizes words rather than quantification in data collection and analysis, emphasizing an inductive approach to the relationship between theory and research, which emphasizes the placement of theory (generation of theory). Therefore, qualitative research is defined as a process of inquiry to understand social problems based on the creation of a complete holistic picture formed by words, reporting the views of informants in detail, and arranged in a natural setting (Sisilah, 2010: 77).

Qualitative research is interpretative research. Thus, theresearcherbias, values, and judgment are stated explicitly in the research report. This kind of openness is considered beneficial and positive (Creswell, 2002: 138). Qualitative analysis is clearly different from quantitative analysis in terms of dividing and combining data collection activities, data analysis, and outcome writing. In qualitative analysis, several activities collectively grab the attention of researchers, including gathering information, sorting information into groups, formatting information into a story or picture, and writing qualitative scripts (Creswell, 2002: 143).

In the case study, Yin (1989) discusses dominant models of data analysis, such as (a) pattern search by comparing results with predicted patterns from theory and literature, (b) developing explanations, where researchers look for causal relationships and/ or digging acceptable or contradictory explanations and try to make an explanation of the case, and (c) time series analysis, in which the researcher traces the pattern of change in a certain period of time, a procedure similar to the time series analysis carried out in experimental and semi experiment (Creswell, 2002: 146). In this study, researchers used the second pattern, namely the development of explanations.

The main components of qualitative research consist of: (1) data, (2) analysis and interpretation procedures and (3) presentation reports (Sumarjo, 2010: 45).

Data is an important material used by researchers to answer questions or test hypotheses and achieve research objectives. Therefore, data and data quality are important subjects in research because they determine the quality of research results. Data is obtained through a process called data collection (Silalahi, 2010: 280). Data collection in this study is to use literature study relating to the object of research and search for audio documents.

The primary data source is an object or original document -raw material from an actor called "first hand information". Data collected from the actual situation when an event occurs is called primary data. Individuals, focus groups and one group of respondents in particular are often used as researchers as primary data sources (Silalahi, 2010: 289). In this study, the primary data sources needed are books by K.H. Asyhari Marzuqi, $\mathrm{MP}_{3}$, and photos.

Secondary data is data collected from second hand or from other sources that were available before the research was conducted. 
Data collected through other available sources is called secondary data (Silalahi, 2010: 291). In this study, the secondary data are several books written by other people, related to K.H missionary activities. Asyhari Marzuqi.

In practice, researchers collect data with observation and documentation techniques. Observation is one of the empirical scientific activities that base the facts of the field and text, through the experience of the five senses without using any manipulation (Hasyim Hasanah, 2016: 21).

Data analysis is needed in research. This study uses case study analysis with a document analysis and audio material analysis approach. In Ananda (2017), Creswell defines a case study (case study) is a model that focuses on the exploration of a "bounded system" for one particular case or in some cases in detail with in-depth data extraction. Various sources of information that are rich in context are carried out for data mining (Ananda, 2017: 259).

Cases can consist of one person, one family, or one community group, and so on which are considered to have a single entity. Researchers can examine roundness and overall cases. The object of study in this case study is one person, namely K.H. Asyhari Marzuqi. Case studies are generally used in the context of exploratory studies only, meaning not testing hypotheses, but developing hypotheses.

A plan for qualitative research procedures must produce a section about narratives arising from data analysis. Qualitative research narratives present information in the form of manuscripts or images (e.g. photographs, video tapes) (Creswell, 2002: 148). This study uses a lot of narrative agreement in describing qualitative narratives by writing the text of the Asyhari Marzuqi K. Da'wah and using quotations from various primary and secondary data sources.

\section{RESULTS AND DISCUSSION}

\section{Intellectual History of KH. Asyhari Marzuqi}

K.H. Asyhari Marzuqi received his first education from the family. Religious education has been inculcated since childhood to him by his parents, both the Qur'an, basic Fiqh, and the science of NahwuSharaf (Munir, 2009: 29-30). K.H. Asyhari Marzuqi was very happy to get religious education since childhood from his family. In addition, at the age of 7 (seven) years, he also entered the People's School (SR).

K.H. Asyhari Marzuqi has a huge enthusiasm for learning. If he has learned, he will forget everything. In fact, it is often K.H. Little Asyhari Marzuqi still holds the book when she sleeps and is covered on his face (Munir, 2009: 31). He has a dream of becoming a scientist. Once a day, K.H. Asyhari Marzuqi, with her sister, K.H. Habib Marzuqi, and his school friend, Asroruddin, who is also still a cousin, sat in the courtyard while chatting (Munir, 2009: 31):

"Tomorrow, what are you going to be?"

"I want to be a rich person," said K.H. Habib Marzuqi, his sister.

"I want to be smart, smart people," said K.H. Asyhari Marzuqi.

K.H ideals Asyhari Marzuqi wants to be a clever person who gets full support from her parents. In fact, in order to provide sufficient time to study, he was not allowed by his father to work in the fields. Instead, his younger brother was given the responsibility to help parents take care of the rice fields.

In 1955, after completing the education of the People's School (SR) in his village, The young K.H. Asyhari Marzuqi was sent by his father to the Krapyak Islamic Boarding School, where his father was also studying there (Munir, 2009: 45). At that time, the Krapyak Islamic Boarding School was a village boarding school full of simplicity. Besides the building is only made of bamboo (gedek), the lighting only uses senthir (kerosene lamps).

At the Krapyak Islamic Boarding School, K.H. Asyhari Marzuqi was confused in choosing the concentration of religious 
education to be pursued, namely memorizing the Qur'an or deepening the yellow book. K.H. R. Abdul Qadir suggested that he memorize the Qur'an as his father had done. Meanwhile, K.H. Ali Ma'shum wants him to deepen the study of the yellow book, especially the interpretation of the Qur'an.

One time, K.H. Ali Ma'shum said, "If you master the book and interpretation, then the Qur'an will follow. However, if you memorize the Qur'an, not necessarily the book and interpretation you master". (Munir, 2009: 46).

Those words that make K.H. Asyhari Marzuqi established himself to choose to study the yellow book study, especially the interpretation of the Qur'an. In addition to reciting, he also took formal education.

After going through the test, K.H Ali Ma'shum, K.H. Asyhari Marzuqi entered the Ibtidaiyah level. But, he only took it in 2 years from what was supposed to be 4 years. At the Tsanawiyah level also 2 years and Aliyah 2 years (Munir, 2009: 48). When entering the first class of Aliyah, he was asked by K.H. Ali Ma'shum to teach his younger siblings.

Around 1957, when the pesantren established the Diniyah Madrasa, K.H. Asyhari Marzuqi is believed to bethefirst head of the madrasa (Munir, 2009: 48). In 1968, he was elected lurah (general chairman) of the Krapyak Islamic Boarding School. It could be said; in this era Krapyak Islamic Boarding School began to modernize the management of Islamic boarding schools. In the hands of the young age administrators commanded by K.H. Asyhari Marzuqi, the Krapyak Islamic Boarding School has organized the organization (Munir, 2009: 54).

In the same year, namely 1968, when he was about to sit in 7 th semester, Prof. Hasbi Asshiddiqi appointed him as an assistant to teach early semester students in Arabic, Nahwu, and Sharaf courses (Munir, 2009: 5152). At that time, he was listed as a student at Sunan Kalijaga IAIN, Syari'ah Faculty, Hadith Interpretation Department.

In 1970, by Hasbi as-Shiddiqie, K.H. Asyhari Marzuqi was asked to submit an application as a lecturer at Sunan Kalijaga IAIN, but he refused the offer because he felt that he was not knowledgeable enough. However, from that offer he was encouraged to seek as much knowledge as possible (Habibah, 2013: 271).

Although being an assistant lecturer at IAIN, K.H. Asyhari Marzuqi also held several arrangements for the Krapyak Islamic Boarding School. In the administrative field, it regulates the administration of correspondence, correspondence management, and structuring of the main santri books. He also arranged rooms, not even the rooms of the santri but also the caregiver's residence. He also gave a name to each complex.

In his management period, K.H. Asyhari Marzuqi also launched an alumni meeting in order to make curriculum guidelines. This draft was deemed necessary because there were many students of the Krapyak Islamic Boarding School who were scattered in various corners of the village, and even established Islamic boarding schools. From the umpteenth alumni, he argued that they needed curriculum guidelines. Even though he continued to study in the Middle East, this plan was finally carried out in 1970.

In the Middle East, K.H. Asyhari Marzuqi received a scholarship to study at Kulliyah Imam al-A'zham, a study group that was founded in the 400 of the Hijriya. His study friends were preachers and scholars from Middle Eastern countries. These Kurdistan people on average have a strong memorizing power. Books like Alfiyah, Shahih Bukhari, and Muslims memorized them all. Even so, K.H. Asyhari Marzuqi at that time still ranked III (Munir, 2009: 62). For this achievement, he received an award from the Indonesian Minister of Information.

After five years getting a scholarship, K.H. Asyhari Marzuqi works at the Indonesian Embassy in Iraq. He works by translating 3 to 4 Arabic-language newspapers into Indonesian every day. In addition, he also became a translator during visits by highranking officials. This activity is very popular 
because even though they work but still on the scientific and information path.

Apart from the demands of work at the embassy, K.H. Asyhari Marzuqi also read books to satisfy his scientific thirst. In Baghdad, it was like finding a heaven of books. Baghdad, especially at the University of Baghdad, provided a fairly representative library (Munir, 2009: 67). In this place, he can find various books, ranging from classical to contemporary. In our reading, he is always looking for books that he hasn't read. When reading one book, and there is a footnote, then he will look for the reference book as in the footnote.

Other activities was carried out by K.H. Asyhari Marzuqi while in the Middle East was active in the organization of Indonesian student associations. In fact, he once headed the Indonesian Students Association (PPI), a cross-sectional and group organization which was also chaired by K.H. Abdurrahman Wahid (Gus Dur) and Irfan Zidny.

On April 7, 1979, K.H. Asyhari Marzuqi was married to Nyai Barokah Nawawi, caretaker daughter of An-Nur Islamic Boarding School, Ngrukem, Bantul, Yogyakarta, K.H. Nawawi Abdul Aziz. Three days after that, K.H. Asyhari Marzuqi drove his wife to the Kediri Islamic Boarding School in East Java to continue memorizing the Qur'an. While two days later, he also returned to Baghdad to continue studying religion. In December 1979, he brought Barokah Nawawi to Baghdad.

At that time, memorizing the Qur'an Barokah had reached 18 juz. Arriving in Baghdad, he was sought out by the husband's Huffadz Madrasa. So, study it in Jami 'Buniyah which is fostered by religious teachers from Egypt, such as Sheikh Muhammad, Shaykh Mahmud Ghorib who has compiled several books (Munir, 2009: 72). K.H. Asyhari Marzuqi drove her to recite the two teachers twice a week.

K.H scientific presentation. Asyhari Marzuqi finally came to an end when his father had prepared a missionary land for him. In November 1985, he left Sheikh Abdul
Qadir al-Jailani to return to his homeland (Munir, 2009: 76).

\section{Persuasive Da'wah of K.H. Asyhari Marzuqi}

In this study, K.H. Asyhari Marzuqi is one of the main components in carrying out the method of persuasion. He acts as a communicator. Meanwhile, the other component is a communication message which in this case is a recitation narrative that has been delivered by K.H. Asyhari Marzuqi.

The combination of communicants (K.H. Asyhari Marzuqi) and messages of da'wah communication (persuasive words in recitation) are persuasive preaching received by the jama'ah (mad'u) as the creation of da'wah messages. Credible communicators and persuasive preaching messages will affect the understanding of mad'u, even following the wishes of communicators with pleasure. However, Mad'u's choice to follow the da'wah message that delivered to him or refused was the will of Allah SWT. He gives guidance to the desired creature.

Here are the results of the research that the researchers obtained:

\section{A. Communicator}

K.H. Asyhari Marzuqi is a person who has high credibility. This can be seen from their self-confidence and skills in socializing with the environment.

At the end of 1985, after returning from Baghdad, K.H. Asyhari Marzuqi immediately occupy the finished house to the west of the cottage building. The first challenge is how to get along with the surrounding community. K.H. Asyhari Marzuqi and his wife were well aware that they lived in a different environment in terms of their religious beliefs. As is common for Kotagede people who are more culturally and organizationally leaning towards Muhammadiyah, even so, the surrounding communities of Prenggan Village. Initially, small allusions often occur. Ever, while walking with his wife, K.H. Asyhari Marzuqi heard whispers 
"Usholli passed, Usholli passed!" However, this did not last long. Because, after this new family is able to socialize, they can be well received. In fact, they often patrol the night together (Munir, 2009: 88).

High credibility in K.H. Asyhari Marzuqi can be seen clearly when the Muhammadiyah leaders actually come to learn from him. Many figures around the Koran during Sunday Morning, even some Muhammadiyah leaders in Kotagede also recite the Koran (Munir, 2009: 88-89).

In addition, K.H. Asyhari Marzuqi was also able to provide religious knowledge originating from prominent scholars. Da'wah methods carried out by K.H. Asyhari Marzuqi was inseparable from influence when he recited at Al-Munawwir Krapyak Islamic Boarding School while also studying in Baghdad. When studying in Baghdad, for example, the methods and concepts of K.H propaganda. Asyhari Marzuqi is the result of reading the books of the works of prominent ulama, Imam Hasan Al-Bana, Sa'id Hawa, Ibn Khaldun, al-Gahazali, Sayyid Qutb, and so on (Munir, 2009: 109).

Besides credibility, K.H. Asyhari Marzuqi also has a sense of empathy for her mad'u. While still being able to carry out da'wah activities, the pain that was being felt was not used as an excuse to stop doing routine preaching activities.

Although health conditions are as perfect as healthy people, K.H. Asyhari Marzuqi continues to carry out his missionary activities to the outskirts, away from crowded halls and facilities. In fact, even in a state of illness, he was present at the recitation program in Gunungkidul, where at that time the attendees could only listen to the cough (Munir, 2009: 110).

K.H. Asyhari Marzuqi also has the ability to get along with the surrounding community. In a study conducted by Aina Noor Habibah, she wrote that from the thoughts of K.H. Asyhari Marzuqi in the field of Sufism, akhlaqh can be clearly seen the difference with the thinking of tasawuf akhlaqi the classical scholars in the early days of the growth of Sufism, especially tasawuf akhlaqi. Among the differences are (Habibah, 2013: 286):

1. Classical scholars emphasize ritual aspects, we can see this from the thoughts of al-Ghazali, al-Jailani, while K.H. Asyhari Marzuqi emphasizes more on social aspects of rituals, since humans are social beings.

2. The first scholars in describing Sufism have had stages to reach the highest level, while K.H. Asyhari Marzuqi does not refer to subjects, but rather emphasizes morality (behavior, behavior), to Allah, the Messenger of Allah, parents, relatives, neighbors.

3. The emphasis of tasawuf akhlaqi on the earlier ulama emphasized morality, while K.H.Asyhari Marzuqi, besidesakhlaq, also emphasized the importance of religious science and technology, a science that is not solely the interests of the world, but also aspects of the hereafter.

Sufism carried out by K.H. Asyhari Marzuqi as stated above places more emphasis on social transgression towards the surrounding community. With it, it is expected that K.H. Asyhari Marzuqi can be well received by the community so that they can develop the religion well without any enmity with the surrounding community.

\section{B. Communication Message}

Based on the research that researchers found, K.H. Asyhari Marzuqi delivered a lot of da'wah material (communication messages) with the persuasion method. Where, he conveyed the message not only giving information but also inviting the communicants to follow the contents of the message. The invitation is subtle not as coercive in nature that tends to force.

The following are the findings along with the results of research from several recitations that have been delivered by K.H Asyhari Marzuqi: 


\section{Recitation One}

In this recitation, K.H. Asyhari Marzuqi related the incident of the chest surgery of the Prophet Muhammad by the Angel Gabriel. In delivering the story of the dissection of the Prophet Muhammad SAW, K.H. Asyhari Marzuqi not only provided information to the worshipers to understand the story of the Prophet Muhammad alone. In addition, he also invited the pilgrims to understand the good qualities that the Prophet Muhammad had so that they could be copied by the pilgrims. He also inserted motivational words to the pilgrims to improve the quality of faith and scientific level.

The phenomenon of the chest surgery of the Prophet Muhammad was purely based on the will and permission of Allah SWT. And, human reason with all its limitations will not be able to reach it. For this reason, it should be necessary for us not to discuss the matter too much, let alone only imitate the opinions of materialists. Because, someone who likes to follow the prayer because parents pray, worship and so forth. All matters of aqidah and faith must not be obedient or just follow along, but must have their own arguments (Marzuqi, 2012: 3).

Associated with a surgical event that is beyond human reason, K.H. Asyhari Marzuqi provides a few simple examples so that pilgrims can easily understand and believe in the nature of jaiz for Allah SWT. First, there is a farmer who has seriously prepared the land, planted, and maintained the plants well. However, the results were not good.

Second, there is a trader who has chosen a strategic place and many people to sell merchandise. However, merchandise is not sold. By K.H. Asyhari Marzuqi explained that these two things could occur because the determinant of success was not an effort but because Allah SWT had the nature of jaiz.

Through this story of the dissection of the Prophet Muhammad SAW also, K.H. Asyhari Marzuqi also invited pilgrims to always cleanse their hearts from the temptations of Satan. Thus the way Allah SWT showed his attention to the Prophet
Muhammad, namely by cleaning the demons from his heart and keeping him away from the first years when the Prophet Muhammad was 2 years 4 months old. So there is no way for demons to enter and there is no demonic courage to draw near to him (Marzuqi, 2012: 4).

In continuing his lecture, he grounded the story of the Prophet Muhammad into every worshiper. K.H. Asyhari Marzuqi said, "This is certainly different from us, which seems there are no demons, but actually there are many demons who come in and even we follow them." (Marzuqi, 2012: 4).

In the study of communication, the ability of K.H. Asyhari Marzuqi in uniting himself with the congregation as in the words included in the method of integration.

More assertive, K.H. Asyhari Marzuqi invited the pilgrims to "operate" the entrance of Satan as done by the Prophet Muhammad. As with the "operation" of the Prophet Muhammad SAW above, our task now is to "operate" our hearts or all possible parts as the entrance of Satan (Marzuqi, 2012: 5).

In addition, K.H. Asyhari Marzuqi also made the incident of the dissection of the Prophet Muhammad SAW as a motivation for parents to instill tawheed to their children since they were children. Allah also wants that the Prophet Muhammad, who since childhood had received guidance from Allah SWT through the mediator of Angel Gabriel, whoever we are if we want to follow the steps of the Prophet Muhammad should have started guidance from childhood, and there must be direction from parents to perfection (Marzuqi, 2012: 5-6).

\section{Recitation Two}

In this second recitation, K.H. Asyhari Marzuqi conveyed the message that the pilgrims were able to avoid the temptations of Satan by repenting Nasuha and taqarrub to Allah SWT. K.H. Asyhari Marzuqi recited while understanding the contents of the letter at-Taubah verse 102: 


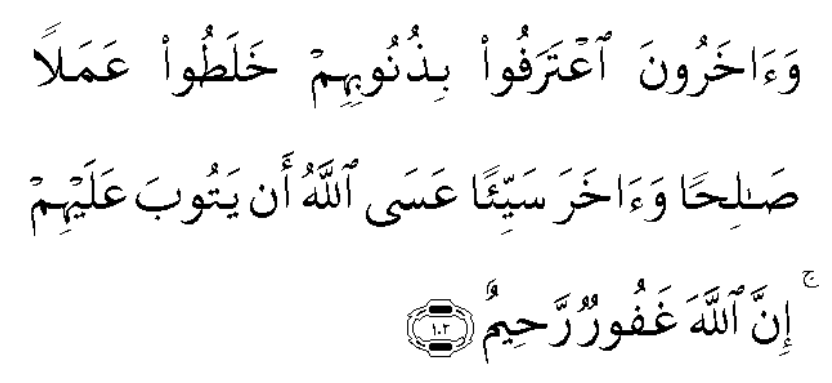

Meaning:

"And (there are also) other people who confess their sins, they mix good work with other bad jobs. May God accept their repentance. Allah is Forgiving, Most Merciful. "(Surah At-Taubah [9]: 102).

From the verse delivered, K.H. Asyhari Marzuqi said that the condition of the people today is a lot that mixes between good and evil deeds. Not a few people who claim to repent but still continue to commit immoral acts. With the integration method, K.H. Asyhari Marzuqi united to the recitation worshipers to introspect themselves by presenting questions:

"From thisverse, let us question ourselves and examine each of us from childhood until now, do we not have sin? Of course not. But we continue to not be able to escape from $\sin$. (Marzuqi, 2012: 12).

After awakening the pilgrims that they are overcome with sin, K.H. Asyhari Marzuqi motivated the pilgrims to read istighfar as was done by Prophet Yunus. Here, researchers found that K.H. Asyhari Marzuqi uses a lot of pay-off methods in giving motivation to worshipers.

K.H. Asyhari Marzuqi explained that remembrance like this if practiced, as read by Prophet Yunus when eaten by fish which he finally survived, will be a lot of wisdom. One of the lessons is, if this sentence is read forty-one times then blown into the palm of the hand and rubbed onto the affected body part, then with Allah's permission the disease will feel lighter.

The aforementioned Information from K.H.Asyhari Marzuqi did not directly instruct the pilgrims to practice zikr as many times as Prophet Yunus said 41 times. However, with this explanation, indirectly K.H. Asyhari Marzuqi provided motivation to the pilgrims to love reading so that they gained wisdom from him.

In order to strengthen the hearts of the pilgrims to practice, K.H. Asyhari Marzuqi also said, "Practice like this has a hadith, in which the Prophet Muhammad said that people who practice it will be granted relief by Allah SWT." (Marzuqi, 2012: 13).

The mention of the hadith implies that K.H. Asyhari Marzuqi delivered the correct message, not lying. This is also important to strengthen the hearts of pilgrims related to faith to practice the material presented by K.H. Asyhari Marzuqi.

K.H. Asyhari Marzuqi also motivated the pilgrims to repent Nasuha. According to him, nasuha repentance is the right dividing line between two periods, namely the period in which humans are in the control of Satan and the time when humans join under the banner of the Most Gracious God (Marzuqi, 2012: 14).

K.H. Asyhari Marzuqi quoted the verse 69 of Nisa as well as explaining that the people who obeyed Allah and His Messenger, as stated in this verse, were those who did the repentance of Nasuha. The Qur'anic letter of the verse 69 is:

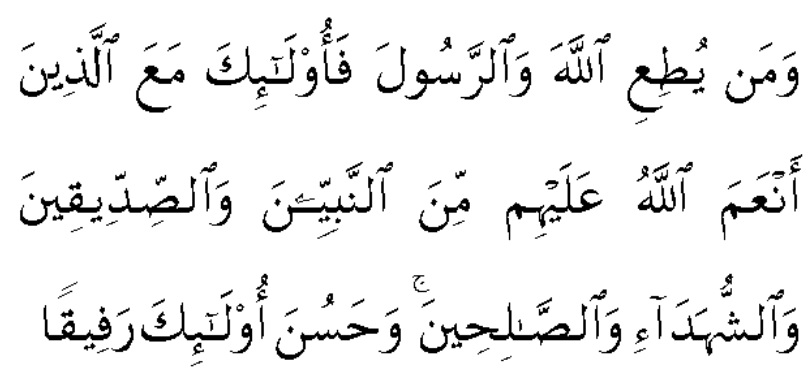

Meaning:

"And whoever obeys Allah and the Messenger (Him), they will be with those who are blessed by Allah, namely, Prophets, Shiddiiqiin, martyrs, and people godly people. And they are the best friends. "(Surat an-Nisaa [4]: 69).

Related to the verse, K.H. Asyhari Marzuqi explained while motivating the pilgrims that by doing nasuha repentance, 
it means that Allah will forgive someone's sins, and will gather them together with the anbiya, auliya ', martyrs, shiddiqin, and salihin.

Once humans come out of the power of Satan with a determined intention to always remember and be close to Allah with a planned will, and that person enters the flag (guarding) of Allah and truly trusts Allah, then Allah really gives to him and masters it and guarantee for the safety of the person (Marzuqi, 2012: 20).

In the statement, K.H. Asyhari Marzuqi does not make the second person an object, but the object is the third person. In fact, the purpose of this submission is addressed to the second person. With the mention of the third person like this, then mad'u does not seem to be the person who becomes the object so it will be comfortable to capture the material.

K.H. Asyhari Marzuqi provides a way for pilgrims to be able to do repentance and taqarrub (draw near to God) as exemplified by the scholars. The pilgrims can choose one of the paths taught by the ulama, both by performing prayers, wirid, recitation, to enter the path of tariqah.

In this statement, K.H. Asyhari Marzuqi again did not patronize the pilgrims by ordering something to do. He actually tells the story that the scholars did different practices, with the same intention, namely taqarrub. And, the pilgrims can imitate the behavior of the scholars according to their respective beliefs and conditions.

At the end of the lecture, K.H. Asyhari Marzuqi gave motivation to the pilgrims to always seek protection from Allah by giving a message, "How much protection Allah has for us depends on how much we go to God and Allah will never lie to us in that matter." (Marzuqi, 2012: 20).

\section{Recitation Three}

In this recitation, K.H. Asyhari Marzuqi invited the pilgrims to recite the feeling of sakinah in the heart. He invited pilgrims to always be calm in various ways, not allowed to be hasty. In inviting worshipers not to be hasty, he exemplified himself in a hurry.

The following are excerpts of the $\mathrm{KH}$ recitation record. Asyhari Marzuqi:

"I am aware of being a parent, when eating in a hurry, even choking, not eating. When in a hurry to travel, sometimes I forget to bring sandals. (Santri asks: "Where is Pak Kiai going to go (why don't I wear sandals)?”).

This method of delivering messages by telling oneself will make the person they are talking to not feel an object. However, the method carried out by K.H. This Asyhari Marzuqi will make the pilgrims also draw conclusions and follow the core of the lessons delivered by K.H. Asyhari Marzuqi.

After awakening the pilgrims to the negative effects of haste (the opposite of sakinah), then K.H. Asyhari Marzuqi continues to motivate instilling sakinah in the heart. He continued his statement that nothing in this world was more important than going to Allah SWT.

\section{CONCLUSION}

Based on the results of the research that has been carried out, it can be concluded that, First K.H intellectual history. Asyhari Marzuqi began since she was a child until the end of her life. In his journey, he was known as a diligent figure since he was still in his father's care, namely K.H. Marzuqi Romli. While studying at Al-Munawwir Islamic Boarding School and at the same time studying at Sunan Kalijaga IAIN, he was able to absorb knowledge well. His love for religious science continues to be developed by studying in the Middle East. In 1985, he spread the knowledge he had by devoting himself to the Nurul Ummah Islamic Boarding School and the Nahdlatul Ulama Organization (NU) by continuing to learn by reading the books written by scholars until the end of his life.

Second, K.H. Asyhari Marzuki has two portraits of persuasive propaganda models, namely himself (communicator) and the contents of his da'wah (message conveyed). First, K.H. Asyhari Marzuki is a 
person who has a strong stance, has a high religious ability, and has good social skills. Second, K.H. Asyhari Marzuki delivered many propaganda messages subtly. The words used are not limited to information to pilgrims. He invited the congregation to continue to foster an understanding of religion while at the same time foretelling it. In giving motivation, he did not seem to force the pilgrims to follow his invitation. In explaining, K.H. Asyhari Marzuki often uses the word "we" which means feeling equal to the worshipers. In addition, in directing the pilgrims to continue to study religion and practice, he presented many stories and the word of God.

Although this research has been maximally pursued, there are still many shortcomings. So that there needs to be some suggestions that the researchers convey, including the implications of this research is to make persuasive preaching K.H. Marzuki's Asyhari is a replica that can be repeated by preachers in the modern era. Moreover, at present many problems occur due to friction between the will of the prosecutors and those charged. In order to create a persuasive atmosphere in preaching, the intellectual history of K.H. Asyhari Marzuqi can also be a beacon of glass for proselytizers and da'i candidates.

For the next researchers, they can examine the effects of persuasive preaching carried out by K.H. Asyhari Marzuki. This is important because of persuasive preaching carried out by K.H. Asyhari Marzuki will be even stronger to become a replica of the present da'i when it can be found that preaching is carried out by K.H. Marzuki's Asyhari has significant results for the congregation.

\section{REFERENCES}

Alfajari, M. Hamam. (2016). "Interaksionalisme Simbolik Santri Terhadap Kiai Melalui Komunikasi di Pondok Pesantren Al-Munawwir Krapyak Yogyakarta", INFORMASI: Kajian Ilmu Komunikasi. Vol. 46. No. 2. Desember.

Alifuddin. Muhammad. (2015). "Dakwah Insklusif dalam Masyarakat Segregatif di Aoma dan Ambesakoa Sulawesi Tenggara”, Jurnal DAKWAH: Media Dakwah dan Komunikasi Islam. Vol. XVI, No. 2.

Ananda, Lisa Rahmi dan Ika Febrian Kristiana. (2017). "Studi Kasus: Kematangan Sosial pada Siswa Homescholling", Jurnal Empati, Vol. 6 No. 1, Januari.

Azami, Ahmad Fadli, (2013). "Pengembangan Aspek Nilai dalam Pendidikan Pesantren di PP Nurul Ummah”, Jurnal Pemikiran Sosiologi, Vol. 2 No. 1, Mei.

D, M. Abzar. (2015). "STRATEGI DAKWAH MASA KINI (Beberapa Langkah Strategis Pemecahan Problematika Dakwah)”, Lentera, Vol. XVIII, No. 1, Juni.

Faizah. (2018). Psikologi Dakwah. Jakarta: Prenanda Media Group.

Farnas, Alwinansyah dan Gumgum Gumelar. (2013). "Efektivitas Persuasif melalui Narasi dan Bukti Statistik terhadap Pengambilan Keputusan Memilih Produk Handphone”. Jurnal Penelitian dan Pengukuran Psikologi. Vol. 2, No. 1, April.

H, Sumarjo. (2010). "Analisis Data Kualtitatif dalam Penelitian Teknik Arsitektur", Inersia. Vol. VI, No. 1, Mei.

Hanana, Alna, Novi Elian dan Revi Marta (2017). "Strategi Komunikasi Persuasif Dalam Menciptakan Masyarakat Sadar Wisata Di Kawasan Wisata Pantai Padang, Kota Padang”, Jurnal Ilmu Sosial Mamangan, Vol. 6, No. 1, JanuariJuni. 
Hasanah, Hasyim. (2016). “Teknik-Teknik Observasi”, Jurnal at-Taqaddum, Vol. 8, No. 1, Juli.

Jamalie, Zulfa. (2015). "Pola Dakwah Pada 'Masyarakat Suku Terasing' di Kalimantan Selatan", Jurnal DAKWAH: Media Dakwah dan Komunikasi Islam. Vol. XVI, No. 1.

Kuntowijoyo, (2004) "Sejarah/Sastra”, Humaniora, Vol. 16. No. 1 Februari.

Maghfiroh, Eva. (2016) “Komunikasi Dakwah; Dakwah Interaktif Melalui Media Komunikasi”, DAKWATUNA: Jurnal Dakwah dan Komunikasi Islam, Vol. 2, No. 1, Pebruari.

Maknun, Lukluil. (2014). “Tradisi Ikhtilaf dan Budaya Damai di Pesantren: Studi kasus PP Nurul Ummah dan Ar-Romli Yogyakarta”, Fikrah, Vol. 2, No. 1, Juni.

Markarma, A. (2014). "Komunikasi Dakwah Efektif dalam Perspektif Al-Qur'an”, HUNAFA: Jurnal Studia Islamika. Vol. 11, No. 1, Juni.

Marzuqi, Asyhari. (2012). 19 Mutiara Ahad Pagi. Yogyakarta: Numeid.

Maulana, Herdiyana. (2013). Psikologi Komunikasi dan Persuasi. Jakarta: Akademia Permata.

Munir, Ahmad. (2009). Mata Air Keikhlasan; Biografi KH. Asyhari Marzuqi. Yogyakarta: Numeid.

Putri, Frieda Isyana, dkk. (2015). “Teknikteknik Persuasif Dalam Media Sosial (Studi Analisis Isi Kualitatif Pada Akun Mentor Parenting Ayah Edy di YouTube)", Jurnal Ilmu Komunikasi.

Habibah, Aina Noor. (2013). "Pemikiran Tasawuf Akhlaqi K.H. Asyhari Marzuqi dan Implikasinya dalam Kehidupan Modern", TEOSOFI: Jurnal Tasawuf dan Pemikiran Islam. Vol. 3, no. 2 Desember.

Ramadhan, Reza Bakhtiar. (2017). "Penggunaan Sorban dalam Bingkai Kesalehan”, PANCAWAHANA: Jurnal Studi Islam, Vol. 12, No. 2, Desember.

Saefulloh, Aris. (2009). "Dakwahtainment:
Komodifikasi Industri Media di Balik Ayat Tuhan", KOMUNIKA, Vol. 3 No.2 Juli-Desember.

Sakdiah, Halimatus. (2015). "Urgensi Interpersonal Skill dalam Dakwah Persuasif”, Jurnal Ilmu Dakwah, Vol. 35, No.1, Januari - Juni.

Sariani, Larasati, dkk. (2014). "Makna Pesan Komunikasi Tradisional Kesenian Masamper (Studi Pada Kelompok Masamper yang ada di Kecamatan Tuminting Kota Manado)", Journal “Acta Diurna” Volume III. No.3.

Silalahi. (2010). Metode Penelitian Sosial. Bandung: Rafika Aditama. .

Slamet. (2009). "Efektifitas Komunikasi dalam Dakwah Persuasif", Jurnal Dakwah, Vol. X, No. 2, Juli-Desember.

Suriani, Julis. (2017). "Komunikasi Dakwah di Era Cyber”, Jurnal An-nida' Jurnal Pemikiran Islam, Vol. 41 No. 2, Desember.

Taruna, Mulyani Mudis. (2009). "Manajemen Kurikulum di Madrasah Diniyah Nurul Ummah Kota Gede D.I. Yogyakarta”, Jurnal Analisa Vol. XVI, No. o1, Januari - Juni.

Yahya, (2016). "Dakwah Islamiyah dan Proselytisme; Telaah Atas Etika Dakwah dalam Kemajuemukan”, INJECT: Interdisciplinary Journal of Communication. Vol 1, No.1, Juni.

Zaini, Ahmad, (2013). "Dakwah Melalui Internet”, AT-TABSYIR: Jurnal Komunikasi Penyiaran Islam. Vol. 1, No. 1, Januari - Juni. 